\title{
Effect of Cutting Conditions on Quality of Milled Surface of Medium-density Fibreboards
}

\author{
Richard Kminiak, ${ }^{a}$ Mikuláš Siklienka, ${ }^{a}$ Rastislav Igaz, ${ }^{a}$ L’uboš Krišśák,, ,* Tomáš Gergel', \\ Miroslav Němec, ${ }^{a}$ Roman Réh, ${ }^{a}$ Alena Očkajová, ${ }^{c}$ and Martin Kučerka ${ }^{c}$
}

\begin{abstract}
The quality of milled surface medium-density fibreboards (MDF) and the effect of the wrong milling direction during the process of automatic milling in real conditions in practice (production machine, production tool, and material) are presented in the paper. Moreover, the effect of the double vs. single bladed milling cutter on the final surface quality with the simultaneous changes in individual parameters of feed rate, thickness of the removed layer, and cutting direction was investigated. The MDF was separated using the strategy "one per pass" with required cutting direction (climb or conventional) and the required thick strips cutting off $(4 \mathrm{~mm}$ to $16+\mathrm{mm})$ at a constant operation speed of the milling cutter $(n=20000$ $\mathrm{min}^{-1}$ ) and a changing feed rate from $v_{f}=1 \mathrm{~m} / \mathrm{min}^{-1}$ to $v_{f}=5 \mathrm{~m} / \mathrm{min}^{-1}$. The use of a multi-bladed milling cutter resulted in the higher quality of the milled surface in all cases (change in feed rate, thickness of removed layer, and cutting direction). The effect of the wrong milling direction during automatic milling was observed only for a single-bladed milling cutter used. An increase in surface roughness $\left(R_{\mathrm{a}}\right)$ occurred; therefore, using the double-bladed milling cutter, which was not associated with an increase in surface roughness, is recommended.
\end{abstract}

Keywords: MDF milling; Machining strategy; Surface roughness; Replaceable blades

Contact information: a: Faculty of Wood Sciences and Technology, Technical University in Zvolen, T. G. Masaryka 24, SK-960 01 Zvolen, Slovak Republic; b: National Forest Centre, Forest Research Institute, T. G. Masaryka 22, SK-960 92, Zvolen, Slovak Republic; c: Department of Technology, Faculty of Natural Sciences, Matej Bel University, Tajovského 40, Banská Bystrica, Slovakia;

* Corresponding author: kristak@tuzvo.sk

\section{INTRODUCTION}

Wood has been an integral part of human life for ages. Wood, as the ultimate renewable material, is a competitive material due to its different chemical, biological, physical, and mechanical properties. Wood has an unquestionable impact on the sustainability of the future society (Mitterpach et al. 2016; May et al. 2017; Potkány et al. 2018; Tudor et al. 2018). Processing wood into a usable material is a complex technological process with an elaborate history. Milling is one of the wood processing methods. The aim of milling is to create a workpiece with the required dimensions, shape, and surface quality (Gaff et al. 2016). Milling is an optimal, productive, and an economically viable choice for wood machining; it is needed to understand all of the milling conditions. It affects economic viability, which is a key pillar of sustainable woodprocessing industry (Hitka and Štípalová 2011; Lorincová et al. 2016; Kampf et al. 2016; Vlčková et al. 2017; Hitka et al. 2018). In terms of technology, milling is defined as the process of material machining with a rotary tool, either with a milling blade or milling head, and is characterized by chip production, where the chip thickness varies from 
minimum to maximum thickness and vice versa (Wyeth et al. 2009; Kubš and Kminiak 2017). The quality of milled surfaces is significantly higher than that of sawn surfaces (Rogozinski et al. 2015; Očkajová et al. 2016, 2018; Rogozinski et al. 2017; Kučerka and Očkajová 2018). However, not even milling guarantees an ideal smooth surface, there is always a certain degree of roughness (Sedlecký 2017). New machining technology makes it easier to obtain high-quality, finished products from materials otherwise difficult to machine. One of these processes is the computerized numerical control (CNC) method (Machado et al. 2009; Li et al. 2016; Liang et al. 2016).

The quality of a milled surface is affected by many factors (Engin et al. 2000). A summary of all the factors that affect the milling process can be defined as the cutting conditions (Békeš et al. 1999; Costes et al. 2004; Welzbacher et al. 2008; Marchal et al. 2009; Škaljič et al. 2009; Darmawan et al. 2011; Gejdoš et al. 2015; Mračková et al. 2016; Sedlecký and Kvietková 2017; Korčok et al. 2018a; Sedlecký et al. 2018). The surface quality is affected especially by the cutting tool used (Curti et al. 2017). In the case of wearing on the tool, an increase in temperature and vibration frequency can occur (Wang et al. 2016; Igaz et al. 2019). Subsequently, a decrease in the quality of milled surface is observed. Vibration can be reduced by using a lower feed rate; however, it changes the quality of machining as well. The tool rake angle was studied by Kuljich et al. (2013), Vančo et al. (2018), and Korčok et al. (2018b). The wear of the tool was studied by Ghosh et al. (2015), Lan et al. (2018), and Koleda et al. (2019). A wide range of collet quality, tool stiffness, offset, collet clamping quality, tooth overlapping, and moisture content of the milled material are other parameters that affect the quality of the milled surface. The effect of the type of milling cutter used (double vs. single-bladed), feed rate, thickness of the removed layer, and the direction of milling (climb vs. conventional) can be observed in the milling process. All mentioned parameters result in surface unevenness of the workpieces and roughness or waviness, ridges, or pulled fibres are manifested this way. The wavy structure obtained is called a cutter-mark and is inherent in the kinematic process of peripheral milling. Sanding and other time and money-consuming operations are examples of the simplest ways of how to reduce or remove the wavy structure (if necessary). Researchers Hynek et al. (2004), Robenack et al. (2013), Robenack et al. (2014), and Gottlöber et al. (2016) dealt with strategies on how to remove "cutter marks." Quality is largely affected by feed per tooth (Felber and Lackner 2005), feed rate, cutting speed (Hernandez and Boulanger 1997; Bian et al. 2019; Wang et al. 2019), and the direction of cutting (Lisičan 2007; Barcík et al. 2014; Pinheiro 2014; Wilkowski et al. 2015; Koleda and Koleda 2016; Curti et al. 2018). Davim et al. (2009) investigated the influence of cutting speed and feed rate parameters through surface roughness in mediumdensity fibreboard (MDF) and observed that there is a decrease in the surface roughness when the spindle speed increases and an increase when the feed rate increases. Therefore, it is better to use a high feed rate. Machining depth and surface roughness change according to the workpiece and the machining parameters within the process and should be investigated in different operating parameters (Deus et al. 2018). Evaluating the surface roughness is important due to the technological properties of the surface: coating adhesion, surface adhesion, color stability etc. (Ozdemir et al. 2007, 2015; Gejdoš and Suchomel 2013; Reinprecht and Pánek 2015; Pánek et al. 2017; Kubovský et al. 2018; Šimůnková et al. 2019).

The effect on quality can be seen considering machined material as well. Material properties affecting the surface can be categorized as anatomical (wood species or material, grain direction, wood defects, etc.), physical (density, moisture content), and mechanical 
(hardness, strength, etc.) properties of the machined material (Eyma 2002; Eyma et al. 2004; Suchomel and Gejdos 2010; Novák et al. 2011; Suchomel et al. 2014; Kvasnová et al. 2016; Igaz et al. 2017; Marková et al. 2018; Klement et al. 2019; Očkajová et al. 2019, Tureková et al. 2019). However, Hernandez et al. (2014) showed that at temperatures higher than $0{ }^{\circ} \mathrm{C}$, wood moisture content does not noticeably affect the mechanical properties inducing the chip fragmentation mechanism.

Modern technology has been adopted in the processing of wood and wood-based materials over the years. The use of $\mathrm{CNC}$ technology has become an everyday reality. CNC machining makes the production preparation process more complicated because the machining process must be planned in detail by designers. Subsequently, in the process of machining itself, there is only minimal chance to correct or optimize it. The process of machining is computerized using the $\mathrm{CNC}$ programs, so the role of a worker is only to control the functions, i.e., engineers and computer operators must be familiar with the process of milling, the effect of material, and technological parameters on the quality of milled material. These CNC programs can be prepared in various ways; the computer program can be handwritten (the computer operator must be skilled in using the programming language code), or in contrast, it can be prepared using more sophisticated parametric programming where the program is already created with automated integration of CAD (Computer-aided design) designs with assembly sequence planners. The production preparation process together with automatic programming introduces errors in the process of machining. However, there are some real-time error compensation techniques (Lenz and Merzenich 1988; Yuan and Ni 1998; Ramesh et al. 2000; TrejoHernandez et al. 2010; Lu and Yeh 2018; Wozniak and Jankowski 2018). Some of the errors are problematic to compensate in real time. One of them is incorrect tool path selection according to the error vectors, which is one of the most common errors. It can result in the change of milling direction (climb milling is changed into conventional milling). This error may be overlooked during the production preparation, and finding it in the production process is difficult. Therefore, whether the error vectors affect the quality of milled surfaces should be questioned, i.e., whether the quality of all milled surfaces is satisfactory.

The aim of this paper is to investigate the effect of the milling cutter (double or single-bladed) on the final surface quality with simultaneous changes in individual parameters (feed rate, thickness of the removed layer, cutting direction), and the effect of the wrong milling direction during the process of automatic milling on the quality of the milled surface in real conditions (production machine, production tool, and material). The experiment, the research subject area, research tools, and specific values are according to the real conditions with the aim to meet the needs of real practice. Similar experiments have been conducted and results were published, however, only under laboratory conditions and standard tool conditions, i.e., climb milling was investigated. The standard way of milling was not studied in the current research (tool with the diameter of more than $100 \mathrm{~mm}$ and revolutions up to $8000 \mathrm{~min}^{-1}$ ), but the milling process using the CNC machining center with a tool diameter of $16 \mathrm{~mm}$ and a revolution of $20000 \mathrm{~min}^{-1}$ was investigated. Moreover, correct and incorrect tool path milling were analyzed, i.e., potential errors of automatic milling were considered as well. Furthermore, the removed layers observed in the research were $4,8,12,16$, and 16+ (standard research deals with removed layers of 1 to $3 \mathrm{~mm}$ ). Surface roughness was evaluated using the mean absolute deviation of the roughness profile $\left(R_{\mathrm{a}}\right)$. 


\section{EXPERIMENTAL}

\section{Materials}

Raw MDF with a thickness $(h)$ of $18 \mathrm{~mm}$, width $(w)$ of 2,800 mm, and length $(l)$ of 2,070 $\mathrm{mm}$ were supplied by Bučina Ltd. (Zvolen, Slovakia) and were used in the experiment. Basic technical parameters provided by the manufacturer are presented in Table 1.

Table 1. Technical Parameters of Raw MDF

\begin{tabular}{|c|c|c|}
\hline Property & Test Method & Request \\
\hline $\begin{array}{c}\text { Thickness tolerance } \\
(\mathrm{mm})\end{array}$ & STN EN 324-1 (1999) & \pm 0.3 \\
\hline $\begin{array}{c}\text { Dimensions tolerance } \\
(\mathrm{mm})\end{array}$ & STN EN 324-1 (1999) & \pm 5.0 \\
\hline $\begin{array}{c}\text { Squareness tolerance } \\
\left(\mathrm{mm} \cdot \mathrm{m}^{-1}\right)\end{array}$ & STN EN 324-2 $(1999)$ & \pm 2 \\
\hline Humidity $\%)$ & STN EN 322 $(1995)$ & 4 to 11 \\
\hline Formaldehyde release & ISO 120 (2001) & $<8 \mathrm{mg} / 100 \mathrm{~g}$ \\
\hline Thickness range $(\mathrm{mm})$ & & $<9<12>19>30$ \\
\hline Bending strength (MPa) & STN EN 310 (1998) & $23 ; 22 ; 20 ; 18 ; 17$ \\
\hline Tensile strength (MPa) & STN EN 319 (1995) & $0.65 ; 0.60 ; 0.55 ; 0.55 ; 0.50$ \\
\hline Swelling after 24 h (\%) & STN EN 317 (1995) & $17,15,12,10,8$ \\
\hline $\begin{array}{c}\text { Modulus of elasticity } \\
(\mathrm{MPa})\end{array}$ & STN EN 310 (1998) & 2,$800 ; 2,500 ; 2,200 ; 2,150 ; 1,900$ \\
\hline
\end{tabular}

General characteristics of the machine were as follows: the experiment was conducted using a 5 axes CNC machining centre SCM Tech Z5 supplied (BOTO Ltd., Nové Zámky, Slovakia). Basic technical and technological parameters are presented in Table 2.

Table 2. Technical and Technological Parameters of CNC Machining Centre SCM Tech Z5

\begin{tabular}{|c|c|}
\hline \multicolumn{2}{|c|}{ Technical Parameters of CNC Machining Centre SCM Tech Z5 } \\
\hline Useful desktop & $X=3,050 \mathrm{~mm} \mathrm{y=1,300} \mathrm{mm} \mathrm{Z}=300 \mathrm{~mm}$ \\
\hline Speed X axis & 0 to $70 \mathrm{~m} \cdot \mathrm{min}^{-1}$ \\
\hline Speed Y axis & 0 to $40 \mathrm{~m} \cdot \mathrm{min}^{-1}$ \\
\hline Speed Z axis & 0 to $15 \mathrm{~m} \cdot \mathrm{min}^{-1}$ \\
\hline Vector rate & 0 to $83 \mathrm{~m} \cdot \mathrm{min}^{-1}$ \\
\hline Technical Parameters of the Main Spindle - Electric Spindle with HSK F63 Connection \\
\hline Rotation axis C & $640^{\circ}$ \\
\hline Rotation axis B & $320^{\circ}$ \\
\hline Revolutions & 600 to $24,000 \mathrm{rpm}$ \\
\hline Power & $11 \mathrm{~kW} 24,000 \mathrm{rpm}$ \\
\hline Maximum tool diameter & $\mathrm{D}=160 \mathrm{~mm}$ \\
\cline { 2 - 2 } & $\mathrm{L}=180 \mathrm{~mm}$ \\
\hline
\end{tabular}

\section{Characteristics of the tool}

In the experiment, the milling cutters used were a single-bladed designation KARNED 4451 (Fig. 1a) and double-bladed designation KARNED 4551 (Fig. 1b) were used, both provided by Karned Tools Ltd. (Prague, Czech Republic). Basic technical and 
technological parameters provided by the manufacturer are mentioned in Tables 3 and 4 . Milling cutters were equipped with reversible blades HW $49.5 \times 9 \times 1.5$ and HW $50 \times 12$ $\times 1.5$ from sintered carbide T03SMG (standard material used for the treatment of highdensity fiberboard (HDF), medium-density fibreboard (MDF), and chipboard), from BOTO Ltd. (Nové Zámky, Slovakia). A specific type of sintered carbide was selected following the previous research (Kminiak et al. 2016) evaluating the operational life of various types of sintered carbide. Low acquisition and operating costs are the main advantages of using the milling cutters with replaceable blades. Moreover, the blades can be changed due to the specific type of milled material. Basic technical parameters provided by the manufacturer of sintered carbide are shown in Table 5.

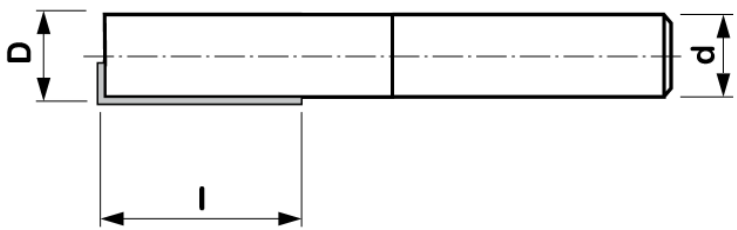

(a)

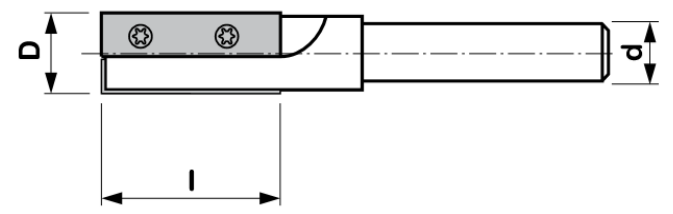

(b)

Fig. 1. Milling cutters used in the experiment: a) single-bladed and b) double-bladed (D operation diameter, I - working length, $\mathrm{d}$ - clamping diameter)

Table 3. Technical and Technological Parameters of Milling Head

\begin{tabular}{|c|c|c|}
\hline $\begin{array}{c}\text { Technical and Technological Parameters of Milling } \\
\text { Head }\end{array}$ & $\begin{array}{c}\text { KARNED } \\
4451\end{array}$ & $\begin{array}{c}\text { KARNED } \\
4551\end{array}$ \\
\hline Total length of the tool & \multicolumn{2}{|c|}{$95 \mathrm{~mm}$} \\
\hline Cutter body diameter & \multicolumn{2}{|c|}{$16 \mathrm{~mm}$} \\
\hline Shank diameter & \multicolumn{2}{|c|}{$12 \mathrm{~mm}$} \\
\hline Height of the cutter body & $49.5 \mathrm{~mm}$ & $50 \mathrm{~mm}$ \\
\hline Number of blades & \multicolumn{2}{|c|}{2} \\
\hline Max. revolutions & \multicolumn{2}{|c|}{$24,000 \mathrm{~min}^{-1}$} \\
\hline Recommended max. feed speed & \multicolumn{2}{|c|}{$5 \mathrm{~min}^{-1}$} \\
\hline$\alpha-$ Clearance angle & \multicolumn{2}{|c|}{$35^{\circ}$} \\
\hline$\beta-$ Cutting wedge angle & \multicolumn{2}{|c|}{$35^{\circ}$} \\
\hline Y - Rake angle & \multicolumn{2}{|c|}{$20^{\circ}$} \\
\hline
\end{tabular}

Table 4. Technical and Technological Parameters of Milling Cutters

\begin{tabular}{|c|c|c|c|c|c|}
\hline Miller & $\begin{array}{c}\text { Working } \\
\text { Diameter } \\
\mathrm{D}(\mathrm{mm})\end{array}$ & $\begin{array}{c}\text { Working } \\
\text { Length } \\
\mathrm{I}(\mathrm{mm})\end{array}$ & $\begin{array}{c}\text { Diameter of the } \\
\text { Chucking Shank } \\
\mathrm{d}(\mathrm{mm})\end{array}$ & $\begin{array}{c}\text { Dimensions of } \\
\text { Used Blades } \\
(\mathrm{mm})\end{array}$ & $\begin{array}{c}\text { Blade } \\
\text { Material }\end{array}$ \\
\hline $\begin{array}{c}\text { KARNED } \\
4451\end{array}$ & 16 & 49.5 & 12 & $49.5 \times 9 \times 1.5$ & T03SMG \\
\hline $\begin{array}{c}\text { KARNED } \\
4551\end{array}$ & 16 & 50 & 12 & $50 \times 12 \times 1.5$ & T03SMG \\
\hline
\end{tabular}

Table 5. Technical Parameters of Sintered Carbide

\begin{tabular}{|c|c|c|c|c|c|c|c|}
\hline $\begin{array}{c}\text { Classes of } \\
\text { TIGRA }\end{array}$ & ISO & US & \multirow{2}{*}{ Binder $\%$} & \multicolumn{2}{|c|}{ Hardness } & \multicolumn{2}{c|}{ Bending Strength } \\
\cline { 4 - 7 } & CODE & CODE & & HV10 & HRA \pm 0.2 & $\mathrm{~N} / \mathrm{mm}^{2}$ & psi \\
\hline T03SMG & K1 & C4++ & 3.5 & 2,100 & 94.6 & 2,400 & 348,000 \\
\hline
\end{tabular}




\section{Methods}

The experiment was performed according to the methodology of Kminiak et al. (2017). First, the milling cutter was fitted with a hydraulic clamp (SOBO $302680291 \mathrm{GM}$ 300 HSK 63F; Gühring KG, Albstadt, Germany) and subsequently inserted into a CNC tool magazine. The original size of the MDF board $\left(2,750 \times 1,840 \mathrm{~mm}^{2}\right)$ was divided into two halves with the same dimensions $\left(2 \times 2,750 \times 868 \mathrm{~mm}^{3}\right)$. A half sheet of MDF board was then placed in a CNC machining center with its longer side in the $\mathrm{X}$-axis and its shorter one in the Y-axis. Then, MDF board was attached using 12 evenly placed suction cups at $120 \times 120 \times 35 \mathrm{~mm}^{3}$ (vacuum pressure was $0.9 \mathrm{bar}$; the suction cups distance from the edge of the MDF board was no more than $50 \mathrm{~mm}$ ). During the experiment, the milling cutter was gripped by the CNC machining center (KARNED 4451 or KARNED 4551) and material was separated using the strategy 'per one pass' with the required cutting direction (climb or conventional) and with the required thick strips of MDF board cutting of ( $4 \mathrm{~mm}$, $8 \mathrm{~mm}, 12 \mathrm{~mm}, 16 \mathrm{~mm}$, or $16+\mathrm{mm})$. Subsequently, the CNC machine tool gripped the circular saw with the diameter of $250 \mathrm{~mm}$ and separated another 5-mm-thick strip of MDF board.

(a)

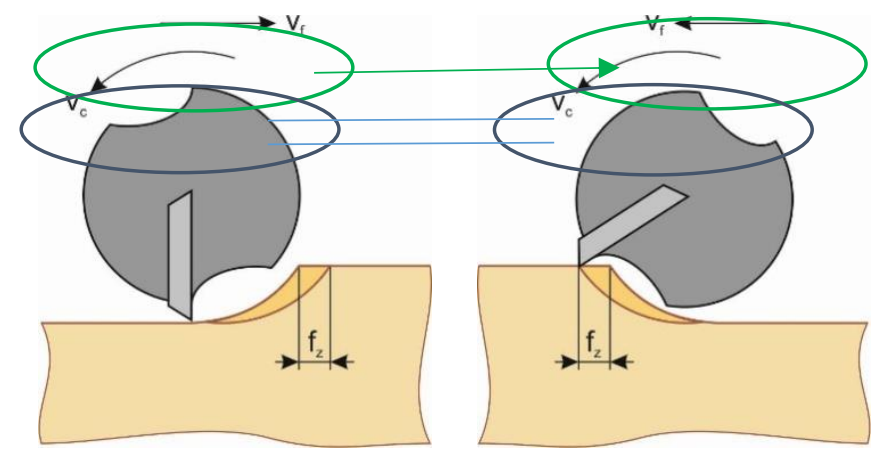

(b)

Fig. 2. Cutting direction: a) conventional and b) climb

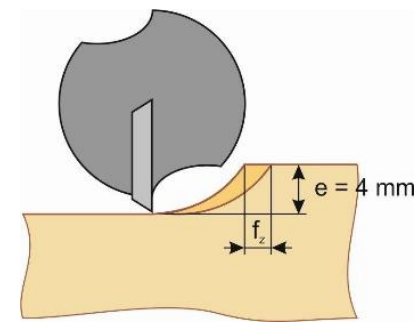

(a)

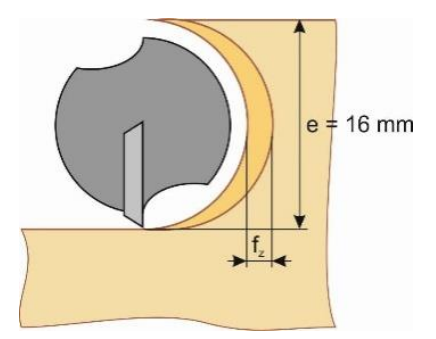

(d)

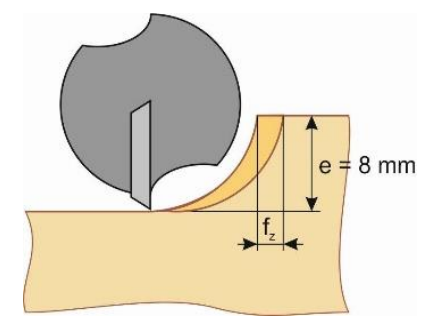

(b)

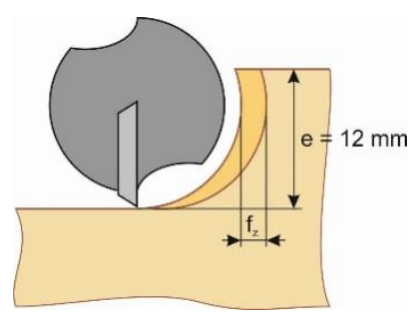

(c)

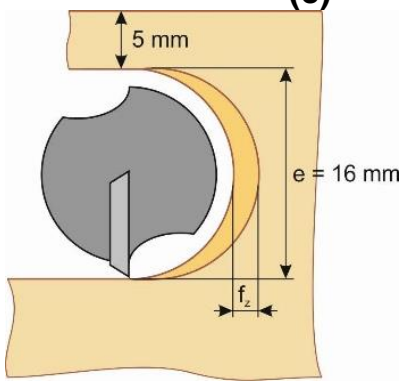

(e)

Fig. 3. Strategy of machining: a) thickness of the removed layer of $4 \mathrm{~mm}$, b) thickness of the removed layer of $8 \mathrm{~mm}, \mathrm{c}$ ) thickness of the removed layer of $12 \mathrm{~mm}$, d) thickness of the removed layer of $16 \mathrm{~mm}$, and e) thickness of the removed layer of $16 \mathrm{~mm}$ plus any residual material 
After the separation of required samples, the MDF board was released and pushed to the end-stop; the process was then repeated with a different combination of technological parameters. The process was conducted at a constant milling cutter operation speed $(n)$ of $20,000 \mathrm{~min}^{-1}$ and a changing feed rate $\left(v_{\mathrm{f}}\right)$ from $1 \mathrm{~m} \cdot \mathrm{min}^{-1}$ to $5 \mathrm{~m} \cdot \mathrm{min}^{-1}$, representing a maximum feed rate of that recommended by the manufacturer. The effect of wrong cutting direction in the process of automatic milling was investigated following the changes in cutting direction. The change in climb milling due to the change of the vector of feed rate to parallel is shown in Fig. 2. The change is not caused by the change in tool rotation (blue circle) but is due to a change in the vector of speed rate (green circle). This is a specific feature of using the CNC machining centers, but for standard machines it does not occur.

The MDF strips with the width of $5 \mathrm{~mm}$ separated using the circular saw were extracted to determine the surface roughness. Samples were extracted according to the methodology of Kminiak et al. (2016), see Fig. 4.

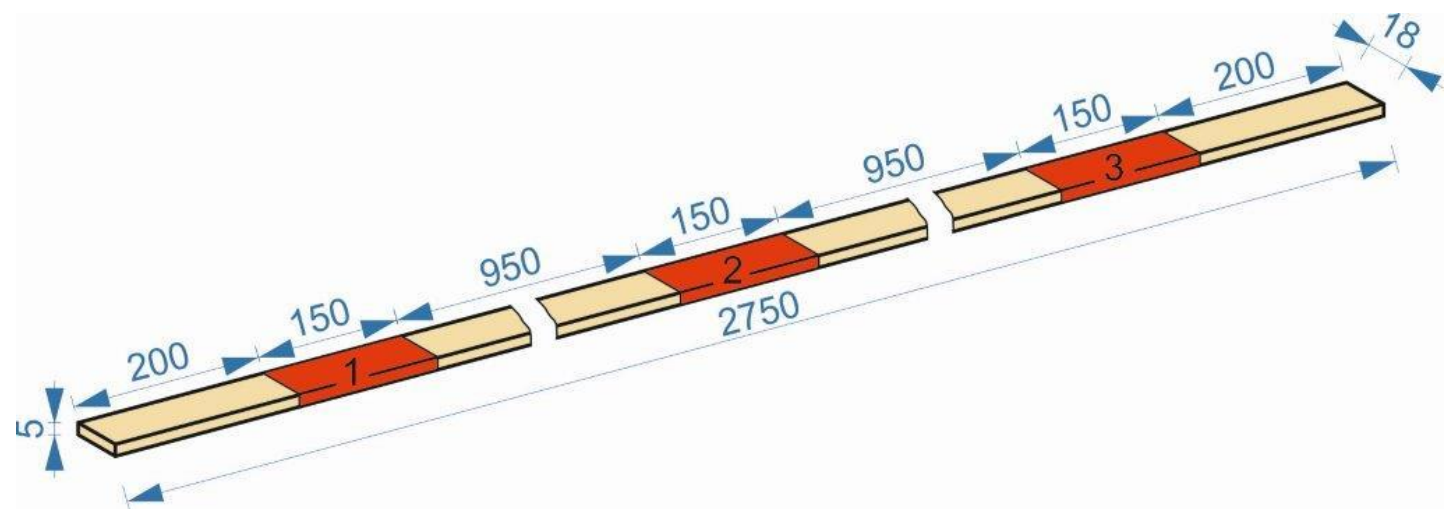

Fig. 4. Methods used to extract samples to determine the surface roughness; all units are expressed in $\mathrm{mm}$

\section{Determination of the surface roughness}

Surface roughness of the samples was measured with a laser profilometer (Fig. 5) (LPM4; Kvant Ltd., Bratislava, Slovak Republic). A profilometer is based on the triangulation principle of laser profilometry.

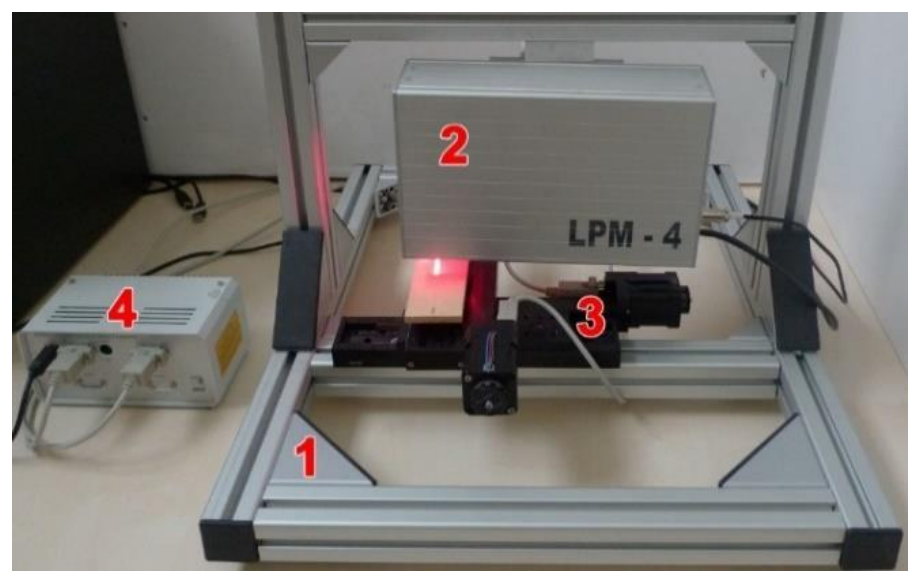

Fig. 5. Laser surface profilometer LPM4 (1 - supporting structure allowing manual preset of working distance and mounting of profilometric head and trolley system, 2 - profilometric head, 3 feed system of the $X Z$ axes, and 4 - control feed system of working desk) 
The image of the laser line is scanned at an angle by a digital camera. Subsequently, an object profile in the cross-section is evaluated from the scanned image. Acquired data are mathematically filtered, and individual indicators of primary profile, as well as profiles of waviness, and roughness, are set (Gaff et al. 2015).

The methodology by Kminiak et al. (2017) considering the standard ISO 4287 (1997), was used to measure the surface roughness. Each sample was measured in three tracks located in the middle of the sample length, evenly spaced across the width of the sample $(4.5,7.5,10.5,13.5 \mathrm{~mm}$ from the edge of the sample). The line length was $60 \mathrm{~mm}$ and the track was oriented in the direction of displacement of the spindle in the milling process (Fig. 6). Surface roughness was evaluated using the mean absolute deviation of the roughness profile $\left(R_{\mathrm{a}}\right)$. This $R_{\mathrm{a}}$ was selected because it is a standard parameter used to determine the roughness of wood and wood-based materials. $R_{\mathrm{a}}$ is considered best suited to evaluate the effect of technology, as material abnormalities typical for wood are eliminated this way. The MDF is a specific wood-based panel that can also be evaluated using $R_{\mathrm{z}}$, but due to the comparison of various materials defined using the $R_{\mathrm{a}}$ value, Ra was preferred in the research. $R_{\mathrm{Z}}$ is the arithmetic mean value of the single roughness depths of consecutive sampling lengths, it means that $R_{\mathrm{z}}$ is the difference between the tallest "peak" and the deepest "valley" in the surface.

Measured values of the mean absolute deviation of roughness profile were evaluated using STATISTICA software (StatSoft, Inc., version 7, Tulsa, OK, USA).

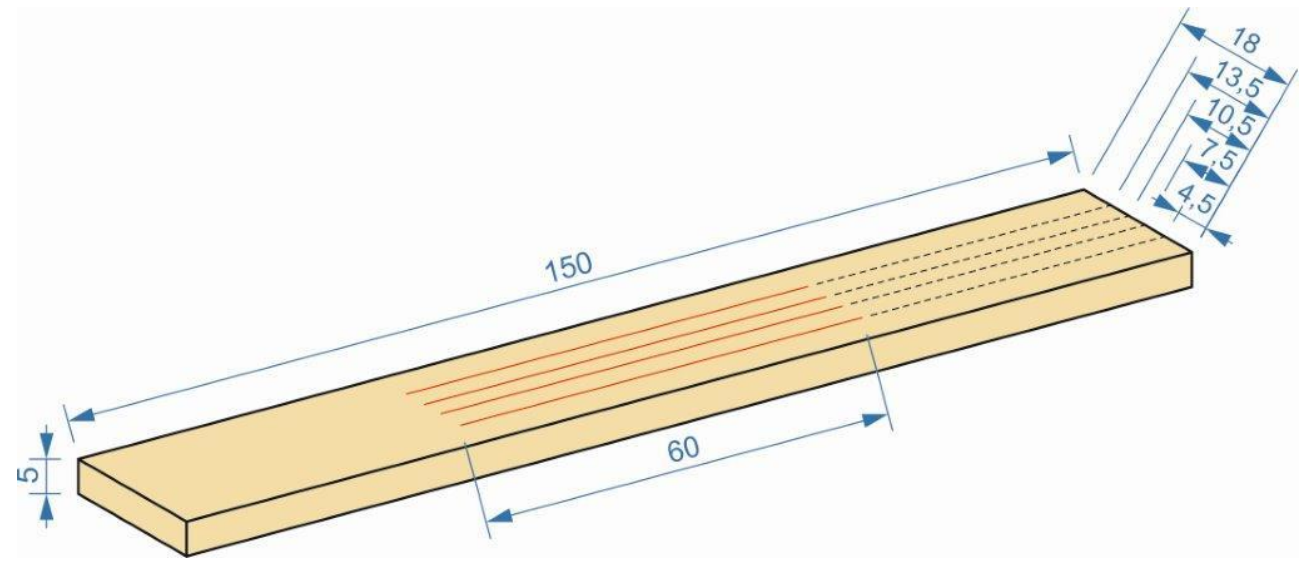

Fig. 6. Placement of tracks due to measuring the surface roughness across the width of the sample; all units are expressed in millimeters

Table 6. Summarized Data

\begin{tabular}{|c|c|}
\hline Factors & Values \\
\hline Type of milling cutter & Single blade $/$ Double blade \\
\hline Feed rate & $V_{f}=1 / 2 / 3 / 4 / 5 \mathrm{~m} \cdot \mathrm{min}^{-1}$ \\
\hline Thickness of the removed layer & $\mathrm{E}=4 / 8 / 12 / 16 /(16+) \mathrm{mm}$ \\
\hline Cutting direction & Convential $/$ Climb \\
\hline
\end{tabular}




\section{RESULTS AND DISCUSSION}

The factor analysis of variance (Table 7) showed that the effect of all examined factors was statistically significant. Following the analysis, examined factors were ordered in terms of the significance as follows: 1 . Type of milling cutter, 2. Feed rate, 3. Thickness of the removed layer, and 4 . Cutting direction.

Table 7. Factor Analysis of Variance for Dependence of Mean Absolute Deviation of Roughness Profile $R_{a}$ on the Examined Factors

\begin{tabular}{|c|c|c|c|c|c|}
\hline Factors & SS & df & MS & $\mathrm{F}$ & $\begin{array}{c}\mathrm{p}- \\
\text { value }\end{array}$ \\
\hline Intercept & $83,343.15$ & 1 & $83,343.15$ & $13,011.00$ & 0.0000 \\
\hline Thickness of the removed layer & 688.10 & 4 & 172.03 & 26.86 & 0.0000 \\
\hline Feed rate & 724.94 & 4 & 181.23 & 28.29 & 0.0000 \\
\hline Type of the milling cutter & $2,875.41$ & 1 & $2,875.41$ & 448.89 & 0.0000 \\
\hline Cutting direction & 144.93 & 1 & 144.93 & 22.63 & 0.0000 \\
\hline $\begin{array}{c}\text { Thickness of the removed layer } \times \text { feed } \\
\text { rate }\end{array}$ & 207.20 & 16 & 12.95 & 2.02 & 0.0107 \\
\hline $\begin{array}{c}\text { Thickness of the removed layer } \times \text { type of } \\
\text { milling cutter }\end{array}$ & 164.24 & 4 & 41.06 & 6.41 & 0.0000 \\
\hline Feed rate $\times$ type of milling cutter & 236.73 & 4 & 59.18 & 9.24 & 0.0000 \\
\hline $\begin{array}{c}\text { Thickness of the removed layer } \times \text { cutting } \\
\text { direction }\end{array}$ & 28.65 & 4 & 7.16 & 1.12 & 0.3471 \\
\hline Feed rate $\times$ cutting direction & 46.19 & 4 & 11.55 & 1.80 & 0.1270 \\
\hline Type of milling cutter $\times$ cutting direction & 241.55 & 1 & 241.55 & 37.71 & 0.0000 \\
\hline $\begin{array}{l}\text { Thickness of the removed layer } \times \text { feed } \\
\text { rate } \times \text { type of milling cutter }\end{array}$ & 162.70 & 16 & 10.17 & 1.59 & 0.0680 \\
\hline $\begin{array}{l}\text { Thickness of the removed layer } \times \text { feed } \\
\text { rate } \times \text { cutting direction }\end{array}$ & 76.87 & 16 & 4.80 & 0.75 & 0.7422 \\
\hline $\begin{array}{c}\text { Thickness of the removed layer } \times \text { type of } \\
\text { milling cutter }\end{array}$ & 114.27 & 4 & 28.57 & 4.46 & 0.0015 \\
\hline $\begin{array}{c}\text { Feed rate } \times \text { type of milling cutter } \times \text { cutting } \\
\text { direction }\end{array}$ & 72.50 & 4 & 18.12 & 2.83 & 0.0243 \\
\hline $1 \times 2 \times 3 \times 4$ & 153.30 & 16 & 9.58 & 1.50 & 0.0965 \\
\hline Error & 3004.22 & 469 & 6.41 & & \\
\hline
\end{tabular}

SS: Sum-of-squares; df: degrees of freedom; MS: Mean squares

The results of the gathered data are presented in the following section. Due to the specific conditions of the authors' experiment, the data gathered cannot be compared to the data of other authors. Comparison of the milling process when the dimensions of tools are completely different would be incorrect (direction of the vector of final cutting speed, etc.).

Following the factor analysis of variance (Table 7), the results showed that the surface roughness was most significantly affected by the type of milling cutter used. The value of the average surface roughness produced with the milling cutter (single-bladed) was $16.26 \mu \mathrm{m}$ with a $95 \%$ confidence interval, and ranged from 15.78 to $16.75 \mu \mathrm{m}$. The value of the average surface roughness produced with the milling cutter (double-bladed) decreased to $11.33 \mu \mathrm{m}$ with a $95 \%$ confidence interval and ranged from 11.08 to $11.60 \mu \mathrm{m}$ Based on the results, the use of the double-bladed milling cutter resulted in a decrease in average surface roughness by $30.3 \%$.

Statistical comparison of the average surface roughness produced with the milling cutter single and double-bladed with a 95\% confidence interval is presented in Fig. 7. 
Comparing the graphs, there was a significant narrowing of the $95 \%$ confidence interval by $45 \%$ when the milling cutter changed from single-bladed to double-bladed. The theoretical assumption that an increase in the number of cutting edges results in higher quality of the surface as a result of the lower feed per tooth with a subsequent chip-thinning effect was confirmed following the values gathered in the experiment.

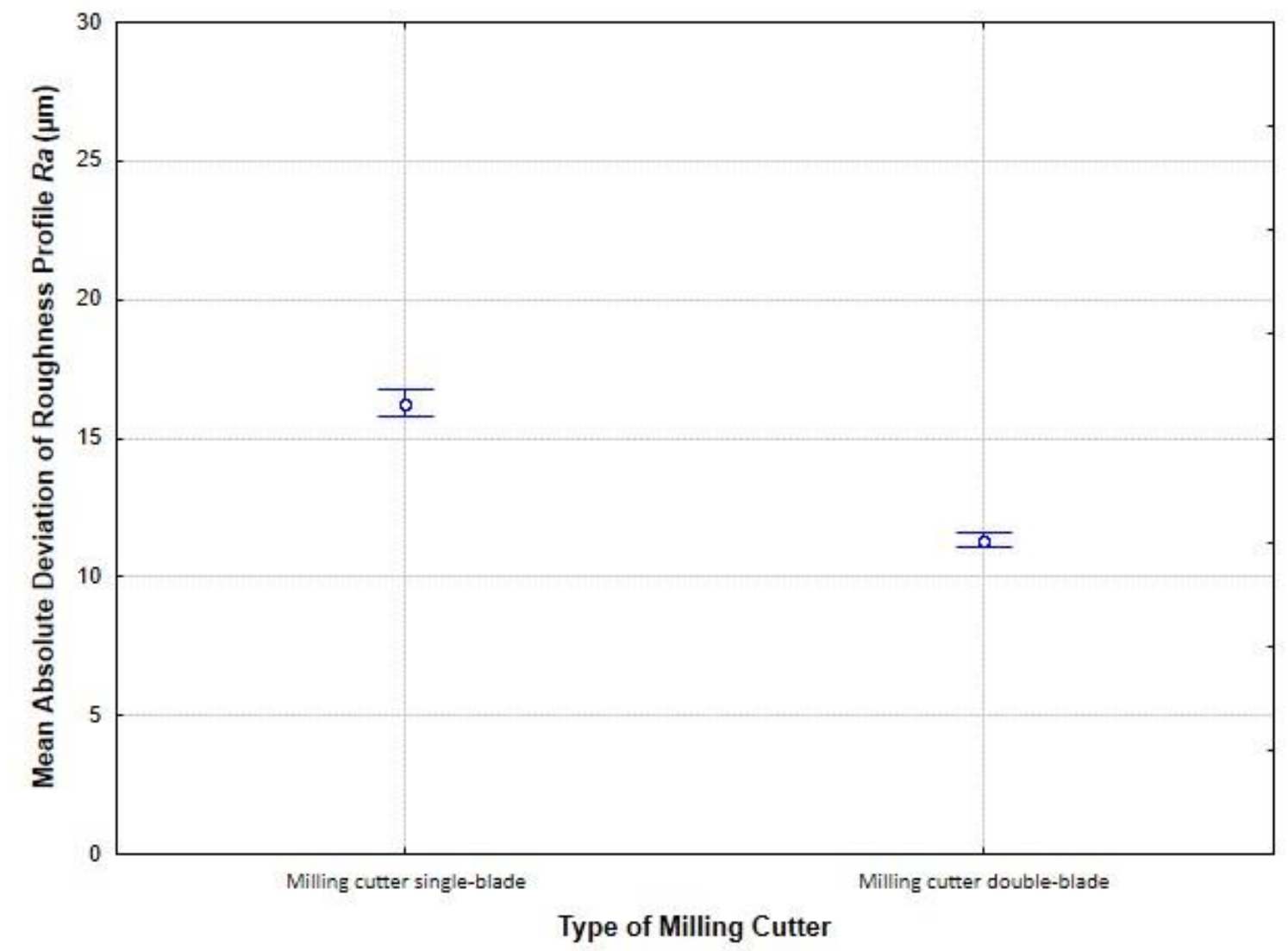

Fig. 7. Relation between mean absolute deviation of roughness profile $\left(R_{a}\right)$ and the type of milling cutter used

The effect of the feed rate was another significant factor affecting the surface roughness. Following the analysis of the mean absolute deviation of the roughness profile shown in Fig. 8, an increase in surface roughness due to a higher feed rate was observed. The most significant and approximately linear increase in the surface roughness when the feed rate $\left(V_{\mathrm{f}}\right)$ ranged from 1 to $3 \mathrm{~m} \cdot \mathrm{min}^{-1}$ was observed with the single-bladed milling cutter. For the double-bladed milling cutter, the most significant increase in surface roughness was observed when the feed rate ranged from 2 to $4 \mathrm{~m} \cdot \mathrm{min}^{-1}$. Following the graph in Fig. 10, differences in an increase in surface roughness depending upon feed rate are shown. For the single-bladed milling cutter, the increase in roughness was approximately twice as large as the double-bladed milling cutter (observed especially when the feed rate was $V_{\mathrm{f}} \leq 3 \mathrm{~m} \cdot \mathrm{min}^{-1}$ ). This could have been due to higher feed per tooth (see Fig. 9). In scientific literature, various works dealing with the single-bladed milling cutter can be found. The same effect of the feed rate during the milling with the single-bladed milling cutter was also reported by Siklienka and Adamcova (2012). The exclusive use of the double-bladed milling cutter is presented in the work of (Kaplan et al. 2018). 


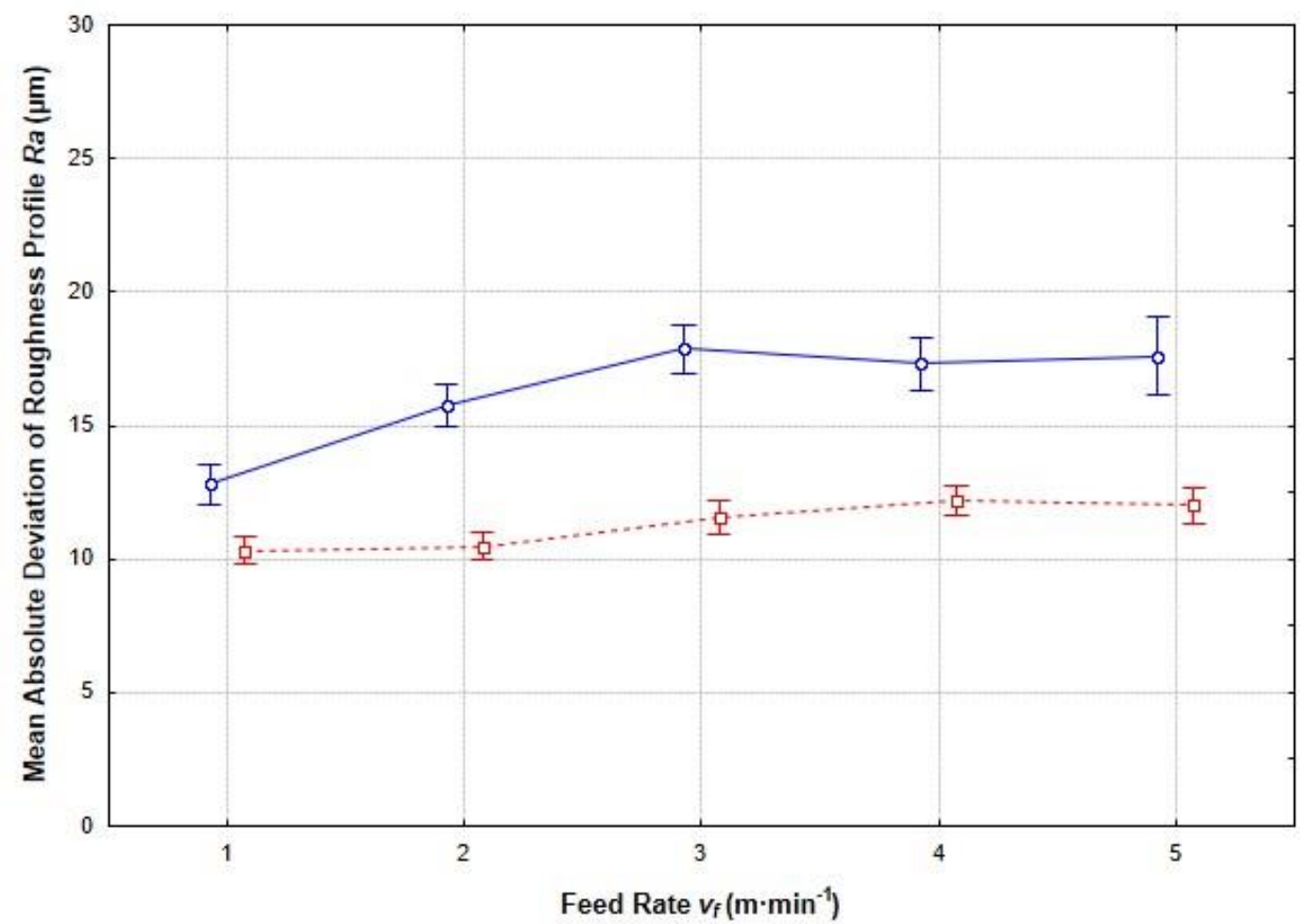

호- Milling cutter single-blade 호- Milling cutter double-blade

Fig. 8. Relation between mean absolute deviation of roughness profile and the feed rate

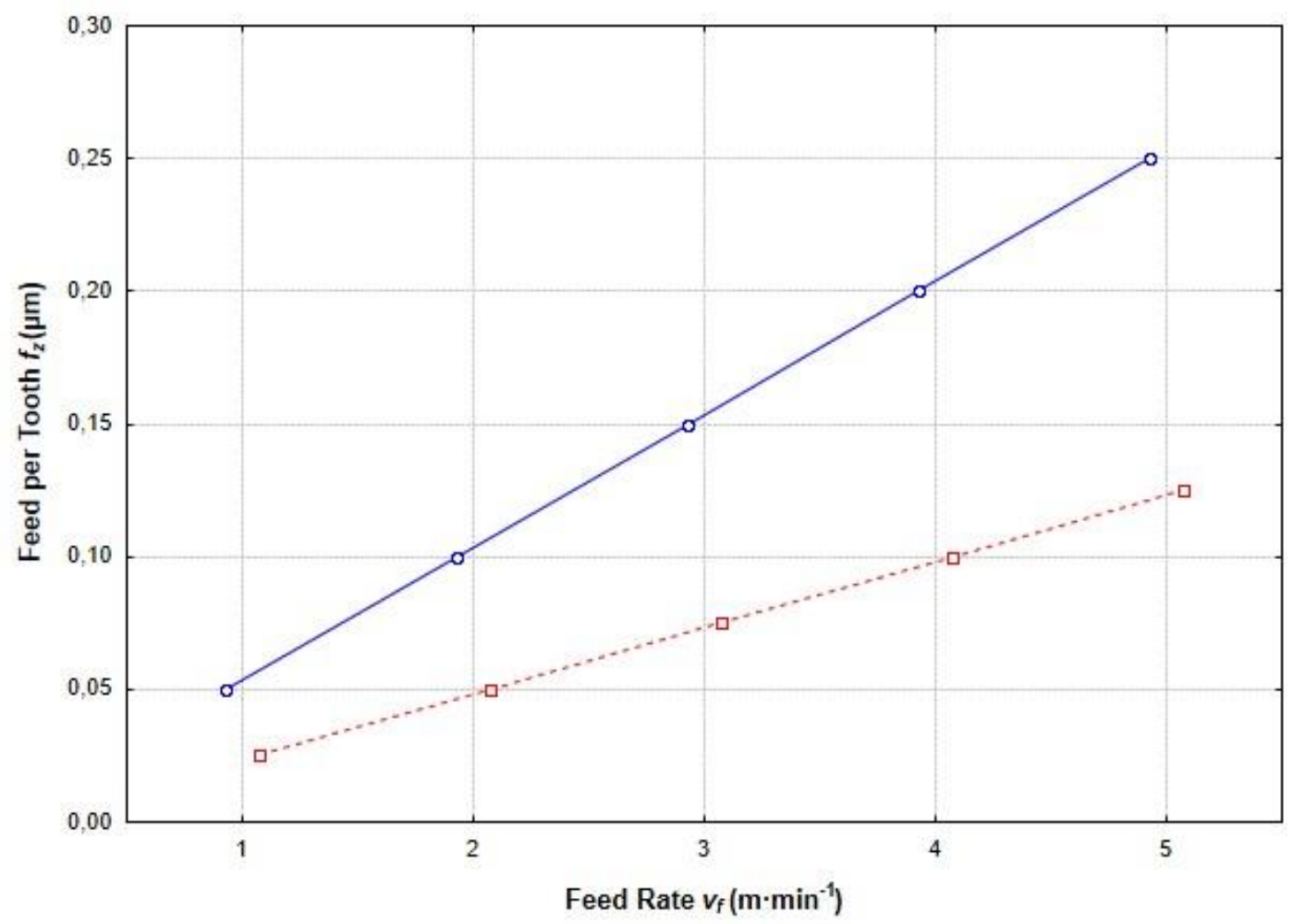

호- Milling cutter single-blade 호- Milling cutter double-blade

Fig. 9. Relation between feed per tooth and the feed rate 
For the single-bladed milling cutter, the roughness of the surface produced was the smallest when the feed rate was $V_{\mathrm{f}}=1 \mathrm{~m} \cdot \mathrm{min}^{-1}$, with $R_{\mathrm{a}}=12.78 \mu \mathrm{m}$. A subsequent increase in the feed rate resulted in an increase in roughness with $R_{\mathrm{a}}=17.85 \mu \mathrm{m}$ when the feed rate was $V_{\mathrm{f}}=3 \mathrm{~m} \cdot \mathrm{min}^{-1}$; an increase of $40 \%$. A further increase in the feed rate caused the increase in surface roughness to remain constant; thus the roughness oscillated around the value of $R_{\mathrm{a}}=17.50 \mu \mathrm{m}$. When testing the double-bladed milling cutter, low roughness values were achieved at a feed rate of $V_{\mathrm{f}}=1 \mathrm{~m} \cdot \mathrm{min}^{-1}$ with $R_{\mathrm{a}}=10.31 \mu \mathrm{m}$. At the maximum feed rate $\left(V_{\mathrm{f}}\right)$ of $5 \mathrm{~m} \cdot \mathrm{min}^{-1}$, the surface roughness increased to a value of $12.00 \mu \mathrm{m}$, i.e., an increase of $16 \%$. Following the calculated data, the observation that an increase in the surface roughness using the single-bladed milling cutter was twice as large as using the double-bladed milling cutter can be seen. This corresponded with an increase in the feed per tooth.

The thickness of the removed layer can be considered the third factor in terms of the significance of its effect on the surface roughness. In comparison to previous factors, the thickness of the removed layer did not affect the feed per tooth, but it caused a change in forming a chip, which was its cross-section. Following the gathered data of the singlebladed milling cutter, the increase in thickness of the removed layer resulted in the increase in surface roughness. However, with the double-bladed milling cutter, no statistically significant effect of the thickness of the removed layer on the change in surface roughness was proved when the thickness of the removed layer ranged from 4 to $16 \mathrm{~mm}$. The assumption that the increased thickness of the removed layer increases the surface roughness as a result of increasing the internal tension in the cutting zone, which should result in cracks in the cutting zone, was rejected (Kminiak et al. 2017).

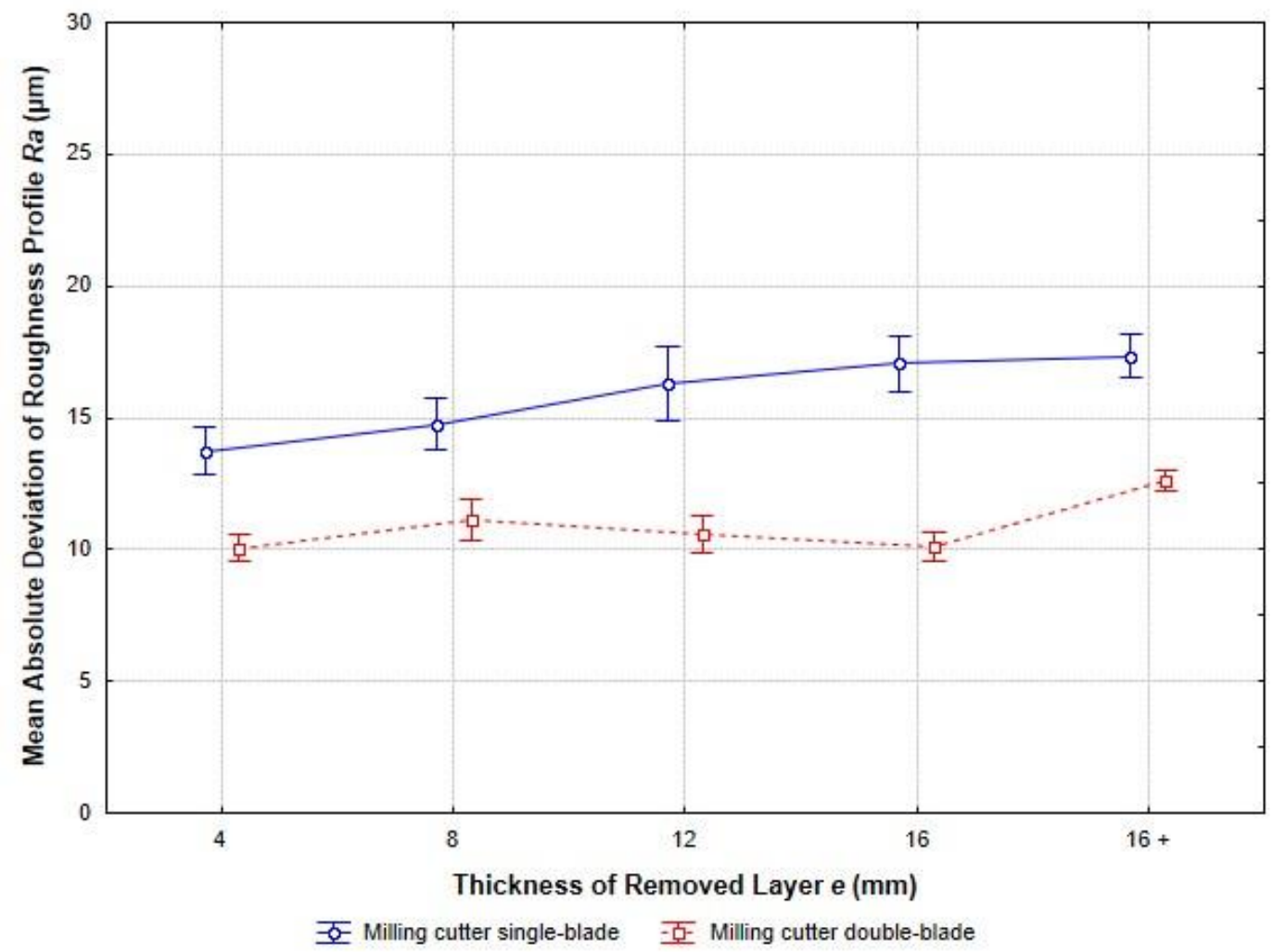

Fig. 10. Relation between mean absolute deviation of roughness profile and the thickness of the removed layer 
A statistically significant difference was observed only for the thickness of the removed layer of $16+\mathrm{mm}$, which was caused by vibration of non-gripped residual material. The relation between mean absolute deviation of roughness profile and the thickness of the removed layer is presented in Fig. 10.

Cutting direction was the last examined factor in terms of its effect on the surface roughness. Data analysis showed that, with the single-bladed milling cutter, the cutting direction affected the final roughness of the milled surface significantly. When climb milling was used, the average value of surface roughness was $R_{\mathrm{a}}=14.9 \mu \mathrm{m}$, whereas when the conventional milling is used, the average surface roughness was $R_{\mathrm{a}}=17.7 \mu \mathrm{m}$. The change in roughness depending upon the cutting direction with the single-bladed milling cutter was $18.8 \%$ for the use of climb milling. When using the double-bladed milling cutter, the effect of the cutting direction on the surface roughness was not identified. Statistical analysis of the mean absolute deviation of roughness profile and a 95\% confidence interval is shown in Fig. 11. For the single-bladed milling cutter, the vector error of the tool path in the process of automatic milling may result in a lower quality of milled surface, i.e., all milled surfaces may not be satisfactory. However, the results allow the statement that using the double-bladed milling cutter does not cause a change in the quality of the milled surface (not even in for changes in vectors of tool paths) to be true. This means that for the doublebladed milling cutter, this error cannot be considered significant.

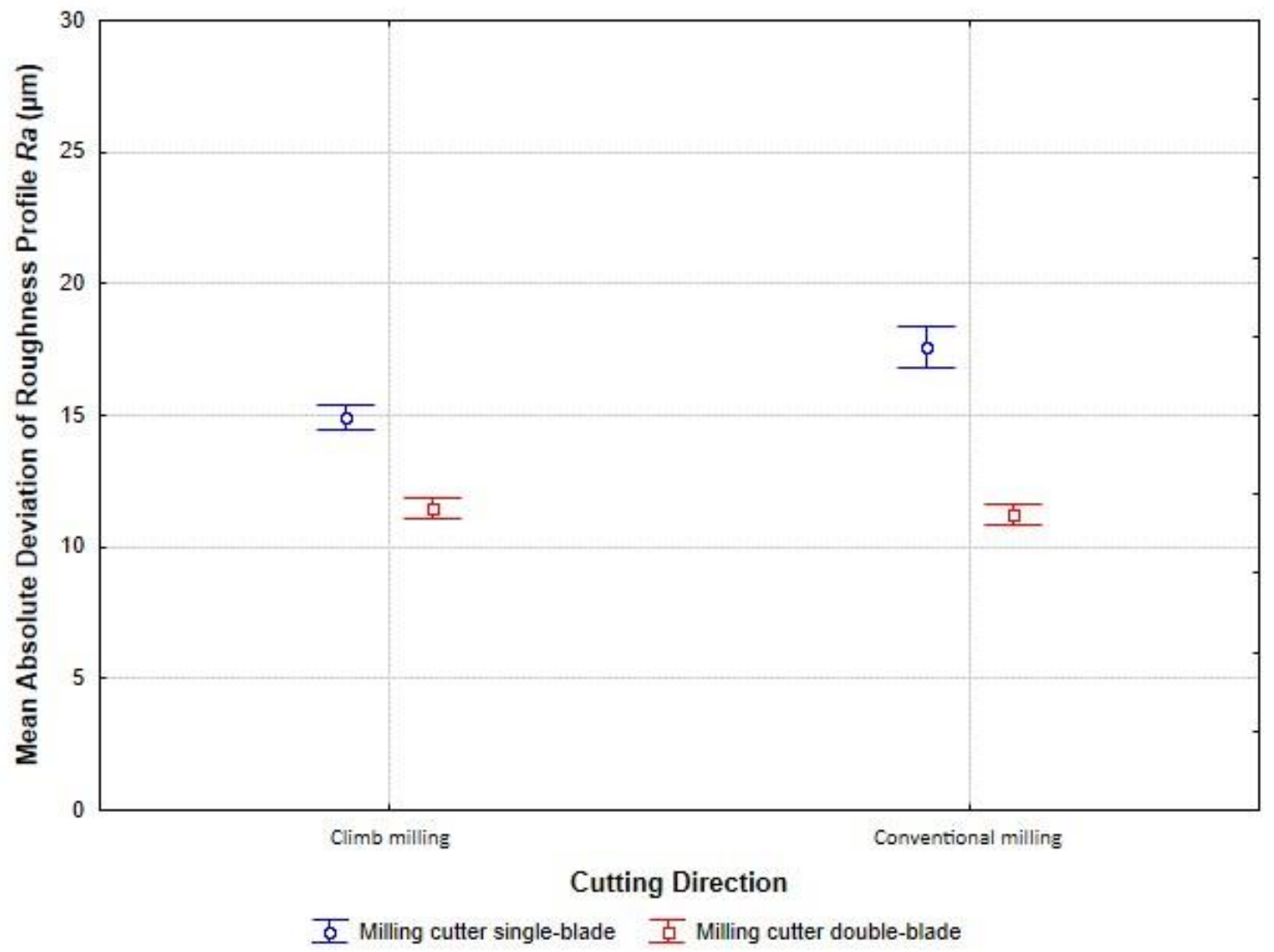

Fig. 11. Relation between mean absolute deviation of roughness profile and the cutting direction 


\section{CONCLUSIONS}

1. In practice, the error caused by the wrong milling direction was observed as the most common error of automatic milling in the production process. In extreme situations, the error was presented acoustically and the tool could be damaged as well. In common situations in practice, the error may not be observed, which can result in the lower quality of milled surfaces, and, moreover, in the tool life.

2. Following the results of the research, the most significant factor affecting the roughness of the milled surface was the type of milling cutter used. Its effect was 17 times larger than the effect of other evaluated factors (feed rate, thickness of the removed layer, cutting direction). In terms of significance, other factors were comparable.

3. The difference in the final surface roughness for the double-bladed milling cutter and the single-bladed milling cutter was $30.3 \%$. Furthermore, the variance of the roughness of the final surface was smaller when the double-bladed milling cutter was used. The increase in the number of cutting edges increased the surface quality as a result of a decrease in feed-per-tooth with a subsequent chip-thinning effect.

4. The increase in feed rate resulted in the increase in surface roughness, whereby the increase was more noticeable for the use of the single-bladed milling cutter than for the double-bladed milling cutter. When using the single-bladed milling cutter, the roughness increased with the feed rate ranging from 1 to $5 \mathrm{~m} \cdot \mathrm{min}^{-1}$, approximately $40 \%$. When the double-bladed milling cutter was used, the roughness increased with the same feed rate approximately $16 \%$, which was significantly lower in value. In both cases, the increase in roughness was due to the increase in feed per tooth.

5. The increase in the thickness of the removed layer caused, for the use of the singlebladed milling cutter, a gradual, almost linear increase in the surface roughness. Cumulating and subsequent vibration of residual material was considered the main reason. For the use of the double-bladed milling cutter, the significantly important increase in the surface roughness was observed only during milling with the thickness of the removed layer over $16 \mathrm{~mm}$. When the values were lower than $16 \mathrm{~mm}$, a statistically significant increase in the surface roughness was not shown. "Nongripping" the residual material (and subsequent vibrations) due to more efficient removing when the double-bladed milling cutter was used (explained by its geometry), was considered the main reason. This theory was confirmed for the use of the fourbladed milling cutter. The increase in the thickness of the removed layer did not affect the surface roughness, seeing that the residual material was removed better in comparison to the double-bladed milling cutter. Following the theory, the increase in the thickness of the removed layer will not affect the surface roughness using the single-bladed milling cutter, but the residual material must be removed during the milling process, for example by the airflow (air blowing).

6. The effect of cutting direction was not statistically significant when the double-bladed milling cutter was used. When using the single-bladed milling cutter, the increase in surface roughness was statistically significant at the level of approximately $19 \%$ for the use of climb milling. 
7. The use of the multi-bladed milling cutter resulted in a higher quality of the milled surface compared to the single-bladed milling cutter in terms of all examined factors. At the same time, using the "double-bladed milling cutter" did not result in a lower quality of the milled surface for the wrong vector of tool path in automatic milling.

\section{ACKNOWLEDGMENTS}

This work was supported by VEGA 1/0485/18 "Machining Strategies for Specific Agglomerated Material Separation Models for Nesting Milling on a CNC Machining Center" and VEGA 1/0717/19 "Assessment of Environmental Impacts of Wood-based Buildings Throughout the Whole Life Cycle".

\section{REFERENCES CITED}

Barcík, Š., Gašparík, M., Houska, A., Razumov, E. Y., and Sedlecký, M. (2014). "Influence of technological factors on the surface quality after milling of thermally modified pine wood," in: Chip and Chipsless Woodworking Processes 2014: Conference Proceedings, Zvolen, Slovakia, pp. 11-22.

Békeš, J., Hrubec, J., Kicko, J., and Lipa, Z. (1999). Teória Obrábania [Theory of Machining], Slovenská Technická Univerzita, Bratislava, Slovakia.

Bian, R., Ding, W., Liu, S., and He, N. (2019). "Research on high performance milling of engineering ceramics from the perspective of cutting variables setting," Materials 12(1), Article Number 122. DOI: 10.3390/ma12010122

Costes, J. P., Pak, L.K., Ji, T., Deces-Petit, C., and Altintas, Y. (2004). “Orthogonal cutting mechanics of maple: Modeling a solid wood - cutting process," Journal of Wood Science 50(1), 28-34. DOI: 10.1007/s10086-003-0527-9

Curti, R., Marcon, B., Collet, R., Lorong, P., Denaud, L. E., and Pot, G. (2017). "Cutting forces and chip formation analysis during green wood machining," in: 23rd IWMS Proceedings, Warsaw, Poland, pp. 152-161.

Curti, R., Marcon, B., Denaud, L., and Collet, R. (2018). "Effect of grain direction on cutting forces and chip geometry during green beech wood machining" BioResources 13(3), 5491-5503. DOI: 10.15376/biores.13.3.5491-5503

Darmawan, W., Rahayu, I., Nandika, D., and Marchal, R. (2011). "Wear characteristics of wood cutting tools caused by extractive and abrasive materials in some tropical woods," Journal of Tropical Forest Science 23(3), 345-353.

Davim, J. P., Clemente, V. C., and Silva, S. (2009). "Surface roughness aspects in milling MDF (medium density fibreboard)," The International Journal of Advanced Manufacturing Technology 40(1-2), 49-55. DOI: 10.1007/s00170-007-1318-z

Deus, P. R., Alves, M. C. S., Vieira, H. A., and Bilesky, L. R. (2018). “Analysis of the cutting parameters in front milling for medium density fiberboard" BioResources 13(2), 3404-3410. DOI: 10.15376/biores.13.2.3404-3410

Engin, S., Altintas, Y., and Amara, F. B. (2000). "Mechanics of routing medium density fiberboard," Forest Products Journal 50(9), 65-69.

Eyma, F. (2002). Caracterisation des Efforts de Coupe de Differentes Essences de Bois a L'aide de Leurs Paramétres Mécaniques [Characterization of the Cutting Efforts of 
Different Wood Species Using Their Mechanical Parameters], Ph.D. Dissertation, Université Henri Poincaré, Nancy, France.

Eyma, F., Meausoone, P. J., and Martin, P. (2004). "Study of the properties of thirteen tropical wood species to improve the prediction of cutting forces in mode B," Annals of Forest Science 61(1), 55-64. DOI: 10.1051/forest:2003084

Felber, G., and Lackner, R. (2005). "Optimization of the production process of sawmill chips for the pulp and paper industry," in: 17th IWMS Proceedings, Rosenheim, Germany, pp. 225-240.

Gaff, M., Kvietková, M., Gašparík, M., Kaplan, L., and Barcík, Š. (2015). "Effect of selected parameters on the surface waviness in plane milling of thermally modified birch wood," BioResources 10(4), 7618-7626. DOI: 10.15376/biores.10.4.7618-7626

Gaff, M., Kvietková, M. S., Gašparík, M., and Slávik, M. (2016). "Dependence of roughness change and crack formation on parameters of wood surface embossing," Wood Research 61(1), 163-174.

Gejdoš, M., and Suchomel, J. (2013). "Potencial of wood for musical instruments in Slovakia," Akustika 20, 16-23.

Gejdoš, M., Lieskovský, M., Slančík, M., Němec, M., and Danielová, Z. (2015). “Storage and fuel quality of coniferous wood chips," BioResources 10(3), 5544-5553. DOI: 10.15376/biores.10.3.5544-5553

Ghosh, S. C., Hernández, R. E., and Blais, C. (2015). "Effect of knife wear on surface quality of black spruce cants produced by a chipper-canter," Wood and Fiber Science 47(4), 1-10.

Gottlöber, C., Wagenführ, A., Röbenack, K., Ahmed, D., and Eckhardt, S. (2016). "Strategies, concepts and approaches to avoid cuttermarks on wooden workpiece surfaces," Wood Material Science and Engineering 11(3), 147-155. DOI: 10.1080/17480272.2015.1133701

Hernandez, R. E., and Boulanger, J. (1997). "Effect of the rotation speed on the size distribution of black spruce pulp chips produced by a chipper-canter," Forest Products Journal 47(4), 43-49.

Hernandez, R. E., Passarini, L., and Koubaa, A. (2014). "Effects of temperature and moisture content on selected wood mechanical properties involved in the chipping process," Wood Science and Technology 48(6), 1281-1301. DOI: 10.1007/s00226014-0673-9

Hitka, M., and Štípalová, L. (2011). “Comparing of employees' motivation level in enterprises of wood working industry with other manufacturing enterprises in Slovak Republic," Drvna Industrija 62(3), 185-192. DOI: 10.5552/drind.2011.1101

Hitka, M., Lorincová, S., Bartáková, G. P., Ližbetinová, L., Štrachoň, P., Li, C., Zaborova, E., Markova, T., Schmidtová, J., and Mura, L. (2018). "Strategic tool of human resource management for operation of SMEs in the wood-processing industry," BioResources 13(2), 2759-2774. DOI: 10.15376/biores.13.2.2759-2774

Hynek, P., Jackson, M., Parkin, R., and Brown, N. (2004). "Improving wood surface form by modification of the rotary machining process," Journal of Engineering Manufacture 218(8), 875-887. DOI: 10.1243/0954405041486073

Igaz, R., Krišsták, L', Ružiak, I, Gajtanska, M., and Kučerka, M. (2017). "Thermophysical properties of OSB boards versus equilibrium moisture content," BioResources 12(4), 8106-8118. DOI: 10.15376/biores.12.4.8106-8118 
Igaz, R., Kminiak, R., Krišsták, L', Němec, M., and Gergel', T. (2019). “Methodology of temperature monitoring in the process of CNC machining of solid wood," Sustainability 11(1), 95-106. DOI: 10.3390/su11010095

ISO 120 (2001). "Plastics. Phenol-formaldehyde mouldings. Determination of free ammonia and ammonium compounds. Colorimetric comparison method," International Organization for Standardizaion, Geneva, Switzerland.

ISO 4287 (1997). "Geometrical product specifications (GPS) — Surface texture: Profile method - Terms, definitions and surface texture parameters," International Organization for Standardizaion, Geneva, Switzerland.

Kampf, R., Lorincová, S., Hitka, M., and Caha, Z. (2016). "The application of ABC analysis to inventories in the automatic industry utilizing the cost saving effect," Nase More 63(3), 120-125. DOI: 10.17818/NM/2016/SI8

Kaplan, L., Sedlecký, M., Kvietková, M., and Sikora, A. (2018). "The effect of thermal modification of oak wood on waviness values in the planar milling process, monitored with contact method," BioResources 13(1), 1591-1604. DOI: 10.15376/biores.13.1.1591-1604

Klement, I., Uhrin, M., and Vilkovska, T. (2019). "Drying the spruce (Picea abies L. Karst.) compression wood," Acta Facultatis Xylologiae Zvolen 61(1), 53-61. DOI: 10.17423/afx.2019.61.1.05

Kminiak, R., Siklienka, M., and Šustek, J. (2016). "Impact of tool wear on the quality of the surface in routing of MDF boards by milling machines with reversible blades," Acta Facultatis Xylologiae Zvolen 58(2), 89-100. DOI: 10.17423/afx.2016.58.2.10

Kminiak, R., Banski, A., and Chakhov, D. K. (2017). "Influence of the thickness of removed layer on the quality of created surface during milling the MDF on CNC machining centers," Acta Facultatis Xylologiae Zvolen 59(2), 137-146. DOI: 10.17423/afx.2017.59.2.13

Koleda, P., Barcík, Š., Svoreň, J., Naščák, L., and Dobrík, A. (2019). “Influence of cutting wedge treatment on cutting power, machined surface quality, and cutting edge wear when plane milling oak wood," BioResources 14(4), 9271-9286. DOI: 10.15376/biores.14.4.9271-9286

Koleda, P., and Koleda, P. (2016). "Optical measurements of sawdust dimensions," Wood Research 61(3), 505-512.

Korčok, M., Vančo, M., Koleda, P., and Barcík, Š. (2018a). "Influence of feed rate and cutting speed on final surface quality after plane milling of oak wood," Acta Facultatis Technicae 23(2), 27-40.

Korčok, M., Koleda, P., Barcík, Š., and Vančo, M. (2018b). "Effects of technical and technological parameters on the surface quality when milling thermally modified European oak wood," BioResources 13(4), 8569-8577. DOI:

10.15376/biores.13.4.8569-8577

Kubovský, I., Oberhofnerová, E., Kačík, F., and Pánek, M. (2018). "Surface changes of selected hardwoods due to weather conditions," Forests 9(9), 557-572. DOI: 10.3390/f9090557

Kubš, J., and Kminiak, R. (2017). "The effect of selected factors on the milled surface quality of thermally modified solid beech," BioResources 12(1), 1479-1490. DOI: 10.15376/biores.12.1.1479-1490

Kučerka, M., and Očkajová, A. (2018). "Thermowood and granularity of abrasive wood dust,” Acta Facultatis Xylologiae Zvolen 60(2), 43-51. DOI:

10.17423/afx.2018.60.2.04 
Kuljich, S., Hernández, R. E., Llavé, A. M., and Koubaa, A. (2013). "Effect of cutting direction, rake angle, and depth of cut on cutting forces and surface quality during machining of balsam fir," Wood and Fiber Science 45(2), 195-205.

Kvasnová, P., Novák, D., Novák, V., and Stebila, J. (2016). "Computer simulation of laser welding technology of chrome-nickel steels in automotive industry and its verification by means of electron microscopy," Manufacturing Technology 16(5), 998-1003.

Lan, T. S., Chuang, K. C., and Chen, Y. M. (2018). "Optimization of machining parameters using fuzzy taguchi method for reducing tool wear," Applied Sciences 8(7), 1011-1024. DOI: 10.3390/app8071011

Lenz, K. J., and Merzenich, W. (1988). "Achievement of accuracy by error compensation of large CMMs," Precision Engineering 10(4), 228-230. DOI: 10.1016/01416359(88)90058-X

Liang, Q., Zhang, D., Wu, W., and Zou, K. (2016). "Methods and research for multicomponent cutting force sensing devices and approaches in machining," Sensors 16(11), 1926-1943. DOI: 10.3390/s16111926

Li, Y., Zhao, Y., Fei, J., Zhao, Y., Li, X., and Gao, Y. (2016). "Development of a tri-axial cutting force sensor for the milling process," Sensors 16(3), 405-428. DOI: $10.3390 / \mathrm{s} 16030405$

Lisičan, J. (2007). Teória a Technika Spracovania Dreva [Theories and Techniques of Wood Processing], Matcentrum, Zvolen, Slovakia, pp. 102-104.

Lorincová, S., Schmidtová, J., and Balážová, Ž. (2016). "Perception of the corporate culture by managers and blue collar workers in Slovak wood-processing businesses," Acta Facultatis Xylologiae 58(2), 149-163. DOI: 10.17423/afx.2016.58.2.16

Lu, Y. C., and Yeh, S. S. (2018). "Using the segmented iterative learning control method to generate volumetric error-compensated part programs for three-axis CNC milling machine tools," Journal of Manufacturing and Materials Processing 2(3), 53-68. DOI: 10.3390/jmmp2030053

Machado, Á. R., Abrao, A. M., Coelho, R. T., Silva, M. B., and Ruffino, R. T. (2009). Teoria da Usinagem dos Materiais, Blucher, Sao Paulo, Brazil.

Marchal, R., Mothe, F., Denaud, L.E., Thibaut, B., and Bleron, L. (2009). "Cutting forces in wood machining - Basics and applications in industrial processes. A reviewCOST Action E35 2004-2008: Wood machining - Micromechanics and fracture," Holzforschung 63(2), 157-167. DOI: 10.1515/HF.2009.014

May, N., Guenther, E., and Haller, P. (2017). "Environmental indicators for the evaluation of wood products in consideration of site-dependent aspects: A review and integrated approach,” Sustainability 9(10), 1897-1928. DOI: 10.3390/su9101897

Mitterpach, J., Hroncová, E., Ladomerský, J., and Štefko, J. (2016). "Quantification of improvement in environmental auality for old residential buildings using life cycle assessment," Sustainability 8(12), 1303-1315. DOI: 10.3390/su8121303

Marková, I., Ladomerský, J., Hroncová, E., and Mračková, E. (2018). “Thermal parameters of beech wood dust," BioResources 13(2), 3098-3109. DOI: 10.15376/biores.13.2.3098-3109

Mračková, E., Krišt'ák, L., Kučerka, M., Gaff, M., and Gajtanska, M. (2016). “Creation of wood dust during wood processing: Size analysis, dust separation, and occupational health," BioResources 11(1), 209-222. DOI: 10.15376/biores.11.1.209222 
Novák, V., Rousek, M., and Kopecký, Z. (2011). "Assessment of wood surface quality obtained during high speed milling by use of non-contact method," Drvna Industrija 62(2), 105-113. DOI: 10.5552/drind.2011.1027

Očkajová, A., Kučerka, M., Krišták, L., Ružiak, I., and Gaff, M. (2016). “Efficiency of sanding belts for beech and oak sanding," BioResources 11(2), 5242-5254. DOI: 10.15376/biores.11.2.5242-5254

Očkajová, A., Kučerka, M., Krišt’ák, L., and Igaz, R. (2018). “Granulometric analysis of sanding dust from selected wood species," BioResources 13(4), 7481-7495. DOI: 10.15376/biores.13.4.7481-7495

Očkajová, A., Barcík, Š., Kučerka, M., Koleda, P., Korčok, M., and Vyhnáliková, Z. (2019). "Wood dust granular analysis in the sanding process of thermally modified wood versus its density," BioResources 14(4), 8559-8572. DOI: 10.15376/biores.14.4.8559-8572

Ozdemir, T., Hiziroglu, S., and Kocapinar, M. (2015). "Adhesion strength of cellulosic varnish coated wood species as function of their surface roughness," Advances in Materials Science and Engineering 2015, Article ID 52496. DOI: $10.1155 / 2015 / 525496$

Ozdemir, T., and Hiziroglu, S. (2007). "Evaluation of surface quality and adhesion strength of treated solid wood," Journal of Materials Processing Technology 186(13), 311-314. DOI: 10.1016/j.jmatprotec.2006.12.049

Pánek, M., Oberhofnerová, E., Zeidler, A., and Šedivka, P. (2017). "Efficacy of hydrophobic coatings in protecting oak wood surface during accelerated weathering," Coatings 7(10), 172-187. DOI: 10.3390/coatings7100172

Pinheiro, C. (2014). Efeitos do Teor de Umidade da Madeira no Fresamento de Pinus Elliottii [Effects of Wood Moisture Content Pinus elliottii on Milling], Master's Thesis, Faculty of Engineering of the Guarantinuetá Campus, UNESP, Guarantinguetá, Brazil.

Potkány, M., Gejdoš, M., and Debnár, M. (2018). "Sustainable innovation approach for wood quality evaluation in green business," Sustainability 10(9), 2984-2998. DOI: 10.3390/su10092984

Ramesh, R., Mannan, M. A., and Poo, A. N. (2000). "Error compensation in machine tools - a review. Part I: Geometric, cutting-force induced and fixture-dependent errors," International Journal of Machine Tools and Manufacture 40(9), 1235-1256. DOI: 10.1016/S0890-6955(00)00009-2

Reinprecht, L., and Pánek, M. (2015). "Effects of wood roughness, light pigments, and water repellent on the color stability of painted spruce subjected to natural and accelerated weathering," BioResources 10(4), 7203-7219. DOI: 10.15376/biores.10.4.7203-7219

Robenack, K., Ahmed, D., Eckhardt, S., and Gottlober, C. (2013). "Peripheral milling of wooden materials without cutter-marks - A mechatronic approach," WSEAS Transactions on Applied and Theoretical Mechanics 8(2), 170-179.

Robenack, K., Ahmed, D., and Gottlober, C. (2014). "Active trajectory tracking of cutting edge in peripheral milling," in: 58th Conference of Ilmenau Scientific Colloquium, Ilmenau, Germany, pp. 2096-3006.

Rogozinski, T., Wilkowski, J., Górski, J., Czarniak, P., Podziewski, P., and Szymanowski, K. (2015). "Dust creation in CNC drilling of wood composites," BioResources 10(2), 3657-3665. DOI: 10.15376/biores.10.2.3657-3665 
Rogozinski, T., Wilkovski, J., Gorski, J., Szymanowski, K., Podziewski, P., and Czarniak, P. (2017). "Technical note: Fine particles content in dust created in CNC milling of selected wood composites," Wood and Fiber Science 49(4), 461-469.

Sedlecký, M. (2017). "Surface roughness of medium-density fiberboard (MDF) and edge-glued (EGP) after edge milling," BioResources 12(4), 8119-8133. DOI: 10.15376/biores.12.4.8119-8133

Sedlecký, M., and Kvietková, M. S. (2017). "Surface waviness of medium-density fibreboard (MDF) and edge-glued panel EGP after edge milling," Wood Research 62(3), 459-470.

Sedlecký, M., Kvietková, S. M., and Kminiak, R. (2018). "Medium-density fiberboard (MDF) and edge-glued panels (EGP) after edge milling-surface roughness after machining with different parameters," BioResources 13(1), 2005-2021. DOI: 10.15376/biores.13.1.2005-2021

Siklienka, M., and Adamcova, E. (2012). "Výskum vplyvu materiálu reverzibilných nožov stopkových nástrojov na kvalitu opracovaného porvchu MDF [Research on the impact of reversible shank tool on MDF quality surface finish]," Trieskové a Beztrieskové Obrábanie Dreva 8(1), 315-323.

Šimůnková, K., Oberhofnerová, E., Reinprecht, L., Pánek, M., Podlena, M., and Štěrbová, I. (2019). "Durability of selected transparent and semi-transparent coatings on Siberian and European larch during artificial weathering," Coatings 9(1), 39-55. DOI: 10.3390/coatings9010039

Škaljič, N., Beljo-Lučič, R., Čavlovič, A., and Obučina, M. (2009). "Effect of feed rate and wood species on roughness of machined surface," Drvna Industrija 60(4), 229234.

STN EN 310 (1998). "Wood-based panels. Determination of modulus of elasticity in bending and of bending strength," Slovak Technical Standards, Bratislava, Slovakia.

STN EN 317 (1995). "Particleboards and fibreboards. Determination of swelling in thickness after immersion in water," Slovak Technical Standards, Bratislava, Slovakia.

STN EN 319 (1995). "Particleboards and fibreboards. Determination of tensile strength perpendicular to the plane of the board," Slovak Technical Standards, Bratislava, Slovakia.

STN EN 322 (1995). "Wood-based panels. Determination of moisture content," Slovak Technical Standards, Bratislava, Slovakia.

STN EN 324-1 (1999). "Wood-based panels. Determination of dimensions of boards. Part 1: Determination of thickness, width and length," Slovak Technical Standards, Bratislava, Slovakia.

STN EN 324-2 (1999). "Wood-based panels. Determination of dimensions of boards. Part 2: Determination of squareness and edge straightness," Slovak Technical Standards, Bratislava, Slovakia.

Suchomel, J., and Gejdos, M. (2010). "The influence of selected factors on the occurrence of false heartwood in beech (Fagus sylvatica)," Acta Facultatis Xylologiae Zvolen 52(1), 5-13.

Suchomel, J., Belanova, K, Gejdos, M., Nemec, M., Danihelova, A., and Maskova, Z. (2014). "Analysis of fungi in wood chip storage piles," BioResources 9(3), 44104420. DOI: 10.15376/biores.9.3.4410-4420

Trejo-Hernandez, M., Osornio-Rios, R. A., Romero-Troncoso, R. J., Rodriguez-Donate, C., Dominguez-Gonzalez, A., and Herrera-Ruiz, G. (2010). "FPGA-based fused 
smart-sensor for tool-wear area quantitative estimation in CNC machine inserts," Sensors 10(4), 3373-3388. DOI: 10.3390/s100403373

Tudor, E. M., Barbu, M. C., Petutschnigg, A., and Reh, R. (2018). “Added-value for wood bark as a coating layer for flooring tiles," Journal of Cleaner Production 170, 1354-1360. DOI: 10.1016/j.jclepro.2017.09.156

Tureková, I., Mračková, E., and Marková, I. (2019). "Determination of waste industrial dust safety characteristics," International Journal of Environmental Research and Public Health 16(12), 2103. DOI: 10.3390/ijerph16122103

Vančo, M., Korčok, M., Koleda, P., and Barcík, Š. (2018). "Effect of technological, material and tool factors on the quality of finished surface when plane milling of thermally treated sessile oak wood," Acta Facultatis Technicae 23(2), 49-62.

Vlčková, M., Gejdoš, M., and Němec, M. (2017). "Analysis of vibration in wood chipping process," Akustika 28(1), 106-110.

Wang, S. M., Chen, Y. S., Lee, C. Y., Yeh, C. C., and Wang, C. C. (2016). "Methods of in-process on-machine auto-inspection of dimensional error and auto-compensation of tool wear for precision turning," Applied Sciences 6(4), 107-122. DOI: 10.3390/app6040107

Wang, R., Wang, B., Barber, G. C., Gu, J., and Schall, J. (2019). "Models for prediction of surface roughness in a face milling process using triangular inserts," Lubricants 7(1), 9-23. DOI: 10.3390/lubricants7010009

Welzbacher, C. B., Brischke, C., and Rapp, A. O. (2008). "Influence of treatment temperature and duration on selected biological, mechanical, physical and optical properties of thermally modified timber," Wood Material Science and Engineering 2(2), 66-76. DOI: 10.1080/17480270701770606

Wilkowski, J., Czarniak, P., Górski, J., Jablonski, M., Pacek, P., Podziewski, P., Szymanowski, K., and Szymona, K. (2015). "Influence of cutting parameters on surface roughness of MDF board after milling and sanding," Annals of Warsaw University of Life Sciences - SGGW Forestry and Wood Technology 92, 473-476.

Wozniak, A., and Jankowski, M. (2018). "Random and systematic errors share in total error of probes for CNC machine tools," Journal of Manufacturing and Materials Processing 2(1), 17-25. DOI: 10.3390/jmmp2010017

Wyeth, D. J., Goli, G., and Atkins, A. G. (2009). "Fracture tohghness, chip types and the mechanics of cutting wood. A review. COST Action E35 2004-2008: Wood machining - Micromechanics and fracture," Holzforschung 63(2), 168-180.

Yuan, J., and Ni, J. (1998) . "The real-time error compensation technique for CNC machining systems," Mechatronics 8(4), 359-380. DOI: 10.1016/S09574158(97)00062-7

Article submitted: September 28, 2019; Peer review completed: December 3, 2019; Revised version received: December 4, 2019; Accepted: December 7, 2019; Published: December 11, 2019.

DOI: 10.15376/biores.15.1.746-766 